\title{
Zinc(II) PVC-Based Membrane Sensor Based on 5,6-Benzo-4,7,13,16,21,24- hexaoxa-1,10-diazabicyclo[8,8,8]hexacos-5-ene
}

\author{
Hassan Ali Zamani, ${ }^{*, a}$ Mohammad Reza Ganjali ${ }^{b}$ and Mohammad Jan Pooyamanesh ${ }^{a}$ \\ ${ }^{a}$ Department of Chemistry, Quchan branch, Islamic Azad University, Quchan, Iran \\ ${ }^{b}$ Department of Chemistry, Tehran University, Tehran, Iran
}

\begin{abstract}
A substância 5,6-benzo-4,7,13,16,21,24-hexaoxa-1,10-diazabiciclo[8,8,8]hexacos-5-eno (BHDE) foi usada como um excelente ionóforo na construção de um sensor de membrana para Zn(II ), em PVC. O melhor desempenho foi obtido para a membrana com a composição de $30 \%$ de policloreto de vinila, 64,5\% de nitrobenzeno (NB), 2,5\% BHDE e 3\% de tetrafenilborato de sódio (NaTPB). Este sensor mostra alta seletividade e sensitividade ao íon zinco, frente a uma grande variedade de cátions, incluindo íons de metais alcalinos, alcalinos terrosos, de transição e de metais pesados. O sensor revelou um grande aumento nos coeficientes de seletividade para íons zinco, em comparação a sensores de zinco previamente relatados. O sensor proposto exibe um comportamento Nernstiniano (com inclinação de 29,1 $\pm 0,4 \mathrm{mV}$ por década) em um grande intervalo de concentração $\left(1,0 \times 10^{-6}\right.$ a $\left.1,0 \times 10^{-1} \mathrm{~mol} \mathrm{~L}^{-1}\right)$, com limite de detecção de $6,3 \times 10^{-7} \mathrm{~mol} \mathrm{~L}^{-1}\left(41,2 \mathrm{ng} \mathrm{mL}^{-1}\right)$. Mostrou, em toda faixa de concentração usada, um tempo de resposta relativamente curto $(<10$ s), e pode ser usado por, no mínimo, 10 semanas em um intervalo de $\mathrm{pH}$ de 2,8 - 7,3. O sensor proposto foi usado com sucesso na determinação direta de íons zinco em águas de descarte de companhias de eletrodeposição de zinco industrial, e também como um eletrodo indicador na titulação com EDTA.
\end{abstract}

The 5,6-benzo-4,7,13,16,21,24-hexaoxa-1,10-diazabicyclo[8,8,8]hexacos-5-ene (BHDE) was used as an excellent ionophore in construction of a $\mathrm{Zn}$ (II) PVC-based membrane sensor. The best performance was obtained with a membrane composition of $30 \%$ poly(vinyl chloride), $64.5 \%$ nitrobenzen (NB), 2.5\% BHDE and 3\% sodium tetraphenylborate (NaTPB). This sensor shows very good selectivity and sensitivity towards zinc ion over a wide variety of cations, including alkali, alkaline earth, transition and heavy metal ions. The sensor revealed a great enhancement in selectivity coefficients for zinc ions, in comparison to the previously reported zinc sensors. The proposed sensor exhibits a Nernstian behavior (with slope of $29.1 \pm 0.4 \mathrm{mV}$ per decade) over a wide concentration range $\left(1.0 \times 10^{-6}-1.0 \times 10^{-1} \mathrm{~mol} \mathrm{~L}^{-1}\right)$ with a detection limit of $6.3 \times 10^{-7} \mathrm{~mol}$

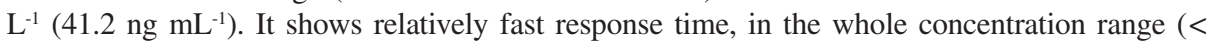
$10 \mathrm{~s}$ ), and can be used for at least 10 weeks in a $\mathrm{pH}$ range of 2.8-7.3. The proposed sensor was successfully used in direct determination of zinc ions in wastewater of industrial zinc electroplating companies, and also as an indicator electrode in titration with EDTA.

Keywords: 5,6-benzo-4,7,13,16,21,24-hexaoxa-1,10-diazabicyclo[8,8,8]hexacos-5-ene, zinc sensor, potentiometry, PVC

\section{Introduction}

The quick determination of minute quantities of ionic species by simple methods is of special interest in analytical chemistry. Construction and application of ionselective electrode as a potentiometric sensor offers interesting advantages such as simplicity, speed, relatively fast response, low cost, wide linear dynamic range and ease of preparation and procedures. These characteristics

* e-mail: haszamani@yahoo.com have inevitably led to the preparation of numerous sensors for several ionic species, and the list of available electrodes has grown substantially over the past years. ${ }^{1}$

Zinc is one of the transition metals, which is used in paint, electroplating, pharmaceutical and chemical industries, and thus occurs widely in the environment. Due to the urgent need for selective potentiometric determination of minute amounts zinc ion, especially in food, biological and environmental samples, many compounds have been employed as an ionophore in the construction of ISEs for zinc ions. ${ }^{2-13}$ 
We have recently reported a number of highly selective and sensitive PVC-membrane ion-selective electrode for various metal ions. ${ }^{11,14-18}$ In this paper, we wish to introduce a highly zinc(II)-selective sensor based on 5,6-benzo4,7,13,16,21,24-hexaoxa-1,10-diazabicyclo[8,8,8]hexacos5-ene (BHDE), as a novel neutral ionophore for monitoring of zinc in industrial samples. BHDE is a cryptand with six oxygen and two nitrogen donor atoms in its structure. It has a rigid cavity $(\sim 2.8 \AA)$ and relatively low solubility in water due to the existence of a benzo group in its structure.

\section{Experimental}

\section{Reagent}

Reagent grade dibutyl phthalate (DBP), nitrobenzene (NB), benzyl acetate (BA), tetrahydrofuran (THF), sodium tetraphenyl borate (NaTPB) and high relative molecular weight PVC were purchased from Merck and used as received. 5,6-Benzo-4,7,13,16,21,24-hexaoxa-1,10diazabicyclo[8,8,8]hexacos-5-ene was purchased from Fluka and used as received. The nitrate and chloride salts of all cations used (all from Merck and Aldrich) were of the highest purity available and used without any further purification except for vacuum drying over $\mathrm{P}_{2} \mathrm{O}_{5}$. Triply distilled de-ionized water was used throughout.

\section{Electrode preparation}

The general procedure to prepare the PVC membrane was to mix thoroughly, $30 \mathrm{mg}$ of PVC, $2.5 \mathrm{mg}$ of BHDE, $3 \mathrm{mg}$ of NaTPB and $64.5 \mathrm{mg}$ of NB. Then the mixture was dissolved in $3 \mathrm{~mL}$ of dry freshly distilled THF. The resulting clear mixture was evaporated slowly until an oily concentrated mixture was obtained. A Pyrex tube (5 $\mathrm{mm}$ i.d.) was dipped into the mixture for about $5 \mathrm{~s}$, so that a transparent membrane of about $0.3 \mathrm{~mm}$ thickness was formed. The tube was then pulled out from the mixture and kept at room temperature for about 2 h. ${ }^{19-22}$ The tube was then filled with internal solution $\left(1.0 \times 10^{-3} \mathrm{~mol} \mathrm{~L}^{-1}\right.$ $\mathrm{ZnCl}_{2}$ ). The electrode was finally conditioned for $24 \mathrm{~h}$ by soaking in a solution containing $1.0 \times 10^{-3} \mathrm{~mol} \mathrm{~L}^{-1}$ zinc nitrate solution. A silver/silver chloride coated wire was used as an internal reference electrode.

The $\mathrm{pH}$ of the all solutions was adjusted at 5.0 by using a buffer of $1.0 \times 10^{-2} \mathrm{~mol} \mathrm{~L}^{-1}$ ammonium chloride/ammonia.

\section{The emf measurements}

All emf measurements were carried out with the following assembly:
$\mathrm{Ag}-\mathrm{AgCl} \mid$ internal solution, $1.0 \times 10^{-3} \mathrm{~mol} \mathrm{~L}^{-1} \mathrm{ZnCl}_{2} \mid$ PVC membrane | sample solution $\mid \mathrm{Hg}-\mathrm{Hg}_{2} \mathrm{Cl}_{2}, \mathrm{KC} 1$ (satd.)

A Corning ion analyzer $250 \mathrm{pH} / \mathrm{mV}$ meter was used for the potential measurements at $25.0^{\circ} \mathrm{C}$. Activities were calculated according to the Debye-Hückel procedure. ${ }^{23}$

\section{Procedure of complexation study}

Conductivity measurements were carried out with a Metrohm 660 conductivity meter. A dip-type conductivity cell made of platinum black, with a cell constant of 0.83 $\mathrm{cm}^{-1}$ was used. In all measurements, the cell was thermostated at $25.0^{\circ} \mathrm{C}$ using a Phywe immersion thermostat. In typical experiments, $25 \mathrm{~mL}$ of a cation nitrate solution $\left(1.0 \times 10^{-4}\right.$ mol L $\mathrm{L}^{-1}$ ) was placed in water jacketed cell equipped with magnetic stirrer and connected to the thermostat circulaing water at the desired temperature. In order to keep the electrolyte concentration constant during the titration, both the starting solution and titrant had the same cation concentration. Then, a known amount of the BHDE $(1.0 \times$ $10^{-2} \mathrm{~mol} \mathrm{~L}^{-1}$ ) solution was added in a stepwise manner using a calibrated micropipette. The conductance of the solution was measured after each addition. Addition of the BHDE was continued until the desired BHDE-to-cation mole ratio was achieved. The 1:1 binding of the cations with BHDE can be expressed by the following equilibrium:

$M^{n+}+L \stackrel{K_{f}}{=} M L^{n+}$

The corresponding equilibrium constant, $K_{\mathrm{f}}$, is given by

$K_{f}=\frac{\left[M L^{n+}\right]}{\left[M^{n+}\right][L]} \times \frac{f_{\left(M L^{n+}\right)}}{f_{\left(M^{n+}\right)} f_{(L)}}$

where $\left[M L^{\mathrm{n}+}\right],\left[M^{\mathrm{n}+}\right],[L]$ and $f$ represent the equilibrium molar concentration of complexes, free cation, free BHDE and the activity coefficient of the species indicated, respectively. Under the dilute condition we used, the activity coefficient of the uncharged ligand, $f_{(\mathrm{L})}$ can be reasonably assumed as unity. ${ }^{24}$ The use of Debye-Hückel limiting law of 1:1 electrolytes, ${ }^{25}$ lead to the conclusion that $f_{\left(M^{\mathrm{n}+}\right)} \approx$ $f_{\left(M L^{\mathrm{n}+}\right)}$, so the activity coefficient in equation (2) is canceled out. Thus, the complex formation constant in term of the molar conductance, $\Lambda$, can be expressed as: ${ }^{26}$

$$
K_{f}=\frac{\left[M L^{n+}\right]}{\left[M^{n+}\right][L]}=\frac{\left(\Lambda_{M}-\Lambda_{o b s}\right)}{\left(\Lambda_{o b s}-\Lambda_{M L}\right)[L]}
$$

Where

$$
K_{f}=C_{L}-\frac{C_{M}\left(\Lambda_{M}-\Lambda_{o b s}\right)}{\left(\Lambda_{o b s}-\Lambda_{M L}\right)}
$$


Here, $\Lambda_{\mathrm{M}}$ is the molar conductance of the cation before addition of BHDE, $\Lambda_{\mathrm{ML}}$ the molar conductance of the complex, $\Lambda_{\text {obs }}$ the molar conductance of the solution during titration, $C_{\mathrm{L}}$ the analytical concentration of the BHDE added, and $C_{\mathrm{M}}$ the analytical concentration of the cation salt. The complex formation constant, $K_{\mathrm{f}}$ and the molar conductance of the complex, $\Lambda_{\mathrm{ML}}$, were obtained by computer fitting of equations (3) and (4) to the molar conductance-mole ratio data using a nonlinear least-squares program KINFIT. $^{27}$

\section{Results and Discussion}

Complexation of BHDE with some cations in acetonitrile

In primary experiments, interaction of BHDE with a number of metal ions was investigated in acetonitrile solution by conductometric method, and the results showed that, in all cases, the ligand to cation mole ratio is 1 . The formation constants $\left(\mathrm{K}_{\mathrm{f}}\right)$ of the resulting 1:1 complexes were evaluated by the computer fitting of the molar conductancemole ratio data to appropriate equations and the results are summarized in Table 1. The obtained formation constants, revealed that BHDE could be used as an excellent ion carrier for preparation of a selective $\mathrm{Zn}$ (II) membrane sensor.

Table 1. The formation constants of BHDE $-\mathrm{M}^{\mathrm{n}+}$ complexes

\begin{tabular}{cccc}
\hline Cation & $\log K_{f}$ & Cation & $\log K_{f}$ \\
\hline $\mathrm{Zn}^{2+}$ & $5.33 \pm 0.06$ & $\mathrm{Ni}^{2+}$ & $2.28 \pm 0.02$ \\
$\mathrm{Sr}^{2+}$ & $2.51 \pm 0.03$ & $\mathrm{Cd}^{2+}$ & $<2$ \\
$\mathrm{Ca}^{2+}$ & $<2$ & $\mathrm{Co}^{2+}$ & $<2$ \\
$\mathrm{Mg}^{2+}$ & $<2$ & $\mathrm{Hg}^{2+}$ & $2.38 \pm 0.03$ \\
$\mathrm{Ba}^{2+}$ & $<2$ & $\mathrm{~Pb}^{2+}$ & $<2$ \\
$\mathrm{~K}^{+}$ & $2.83 \pm 0.04$ & $\mathrm{La}^{3+}$ & $<2$ \\
$\mathrm{Na}^{+}$ & $2.67 \pm 0.02$ & $\mathrm{Ce}^{3+}$ & $<2$ \\
$\mathrm{Cu}^{2+}$ & $2.64 \pm 0.04$ & $\mathrm{Cr}^{3+}$ & $<2$ \\
\hline
\end{tabular}

Response of the sensors based on BHDE to Zn(II) ions

In next experiment, BHDE was used as a neutral ionophore to prepare a number of membrane electrodes for some metal ions and their potential responses were measured, and the results are shown in Figure 1a and 1b. It can be seen that the membrane based on BHDE displays a Nernstian response to the concentration of $\mathrm{Zn}$ (II) ions in a wide concentration range.

Effect of membrane composition on the potential response of the $\mathrm{Zn}(I I)$ sensor based on BHDE

The PVC-based membrane sensor based on BHDE generated stable potential response in aqueous solutions containing zinc ions after conditioning for about $12 \mathrm{~h}$ in a $1.0 \times 10^{-2} \mathrm{~mol} \mathrm{~L}^{-1}$ zinc nitrate solution. Table 2 shows the
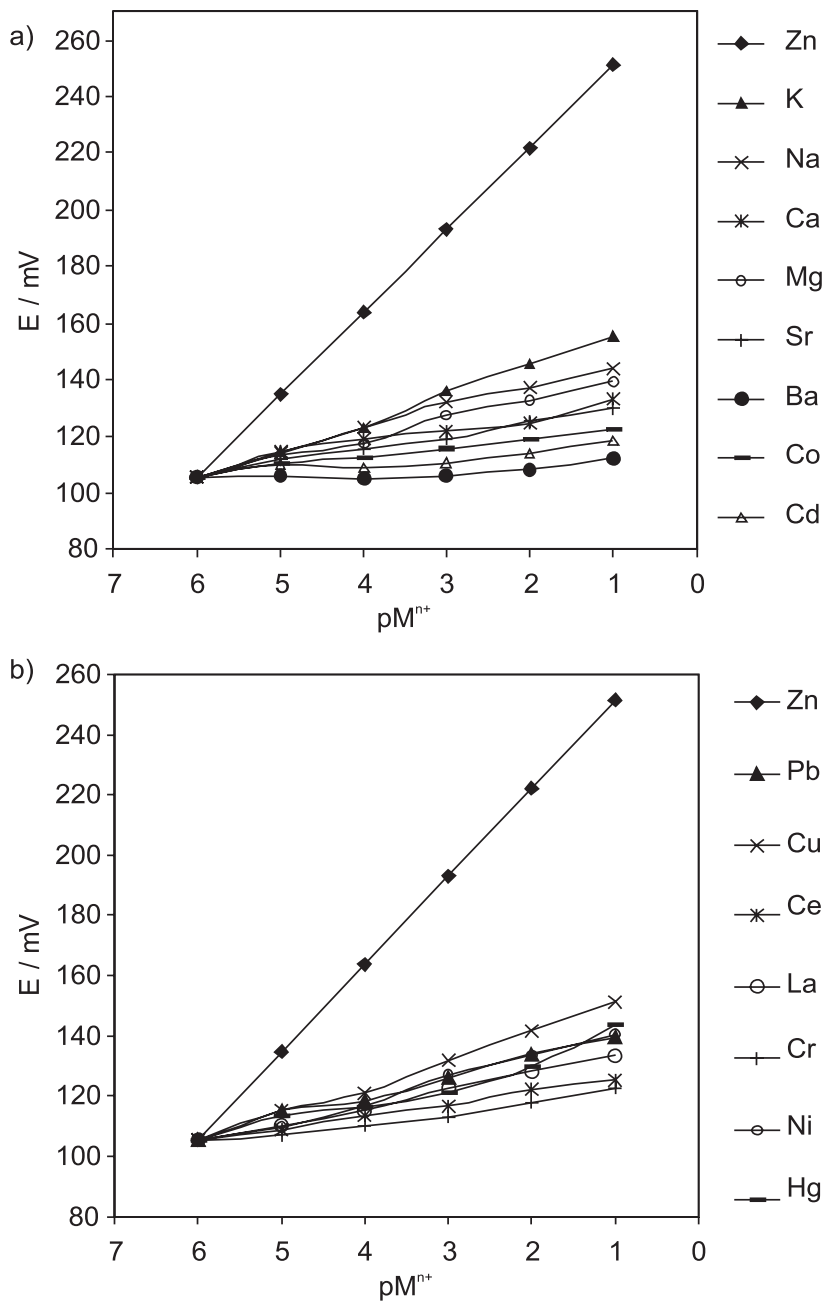

Figure 1. Potential responses of various ion-selective electrodes based on BHDE.

data obtained with membranes having various ratios of different constituents. The potential responses of all of the membrane sensors were studied in a wide range of concentrations of zinc nitrate solution. Table 2 shows that the total potentiometric response of the electrode towards $\mathrm{Zn}$ (II) ions is dependent on the concentration of the BHDE that is incorporated within the membrane. As can be seen from Table 2, increasing the amount of BHDE up to 2.5\% resulted in the membranes (No. 5 and 6) that display larger slopes. A maximum slope of $29.1 \pm 0.4 \mathrm{mV}$ per decade of zinc concentration was observed for the membrane No. 7 with $2.5 \%$ of BHDE.

It is well established that the presence of lipophilic anions in cation-selective membrane electrodes diminishes the ohmic resistance, enhances the response behavior and selectivity, and increases the sensitivity of the membrane electrodes. ${ }^{28,29}$ Ionic additives are ionic exchangers which themselves induce a selective response if no or only an insufficient amount of ionophore is present. Therefore, their concentration must be 
Table 2. Optimization of membrane ingredients

\begin{tabular}{|c|c|c|c|c|c|c|}
\hline \multirow{2}{*}{$\begin{array}{c}\text { Sensor } \\
\text { No. }\end{array}$} & \multicolumn{4}{|c|}{ Composition (wt. \%) } & \multirow{2}{*}{$\begin{array}{c}\text { Slope } \\
\left(\mathrm{mV} \mathrm{decade}{ }^{-1}\right)\end{array}$} & \multirow{2}{*}{$\begin{array}{l}\text { Concentration } \\
\text { range }\left(\mathrm{mol} \mathrm{L}^{-1}\right)\end{array}$} \\
\hline & PVC & Plasticizer & BHDE & NaTPB & & \\
\hline 1 & 30 & $\mathrm{NB}, 69$ & 1 & 0 & $12.3 \pm 0.3$ & $1.5 \times 10^{-2}-1.0 \times 10^{-4}$ \\
\hline 2 & 30 & $\mathrm{NB}, 68$ & 2 & 0 & $18.4 \pm 0.5$ & $1.0 \times 10^{-1}-1.0 \times 10^{-5}$ \\
\hline 3 & 30 & NB, 67 & 3 & 0 & $17.2 \pm 0.4$ & $1.0 \times 10^{-1}-1.0 \times 10^{-5}$ \\
\hline 4 & 30 & NB, 67.5 & 2.5 & 0 & $18.8 \pm 0.6$ & $1.0 \times 10^{-1}-1.0 \times 10^{-5}$ \\
\hline 5 & 30 & $\mathrm{NB}, 66.5$ & 2.5 & 1 & $24.2 \pm 0.2$ & $1.0 \times 10^{-1}-1.0 \times 10^{-6}$ \\
\hline 6 & 30 & $\mathrm{NB}, 65.5$ & 2.5 & 2 & $26.5 \pm 0.5$ & $1.0 \times 10^{-1}-1.0 \times 10^{-6}$ \\
\hline 7 & 30 & $\mathrm{NB}, 64.5$ & 2.5 & 3 & $29.1 \pm 0.4$ & $1.0 \times 10^{-1}-1.0 \times 10^{-6}$ \\
\hline 8 & 30 & $\mathrm{NB}, 63.5$ & 2.5 & 4 & $27.2 \pm 0.6$ & $1.0 \times 10^{-1}-1.0 \times 10^{-6}$ \\
\hline 9 & 30 & BA, 64.5 & 2.5 & 3 & $24.7 \pm 0.5$ & $1.0 \times 10^{-1}-1.0 \times 10^{-6}$ \\
\hline 10 & 30 & DBP, 64.5 & 2.5 & 3 & $23.6 \pm 0.3$ & $1.0 \times 10^{-1}-1.0 \times 10^{-6}$ \\
\hline
\end{tabular}

adjusted carefully. As can be seen from Table 2, the slope of the sensor in the absence of NaTPB is lower than the expected Nernstian value (membranes Nos. 1-4), while, addition of 2-3\% NaTPB will increase the sensitivity of the electrode response considerably, so that the membrane electrode demonstrates a near Nernstian behavior (membrane No. 6). As can be seen from Table 2, addition of more than $3 \%$ of NaTPB $(4 \%)$ to the membrane causes a decreasing in slope from 29.1 to $27.2 \mathrm{mV}$ per decade. This is due to the increasing of the mole ratio of NaTPB/BHDE than one.

However, the membrane sensor with composition of $30 \%$ PVC; $64.5 \% \mathrm{NB} ; 3 \% \mathrm{NaTPB}$, and $2.5 \% \mathrm{BHDE}$ exhibits the best performance.

\section{Calibration graph and statistical data}

The optimum responses of the sensors based on BHDE were evaluated after conditioning of the membranes with same composition, for different periods of time in $1.0 \times$ $10^{-2} \mathrm{~mol} \mathrm{~L}^{-1}$ zinc nitrate solution. The slope obtained using $12 \mathrm{~h}$ of conditioning was closer to the theoretically expected slopes, on the basis of the Nernst equation. Longer conditioning times produced no further improvements in the response. The optimum conditioning solution was determined to have a concentration of about $1.0 \times 10^{-2} \mathrm{~mol} \mathrm{~L}^{-1}$.

The potential response of the $\mathrm{Zn}$ (II) $\mathrm{PVC}$-based membrane sensor at varying concentrations of zinc nitrate (Figure 2) indicates a linear working concentration range from $1.0 \times$ $10^{-1}$ to $1 \times 10^{-6} \mathrm{~mol} \mathrm{~L}^{-1}$. The slope of the calibration graph was $29.1 \pm 0.4 \mathrm{mV}$ per decade of zinc ions concentration. The detection limit of the sensor that determined from the intersection of the two extrapolated segments of the calibration graph was $6.3 \times 10^{-7} \mathrm{~mol} \mathrm{~L}^{-1}\left(41.2 \mathrm{ng} \mathrm{mL}^{-1}\right)$. The standard deviation for ten replicate measurements was $\pm 0.6 \mathrm{mV}$.

\section{Life-time study}

For evaluation of stability and lifetime of the proposed membrane sensor, four same electrodes were chosen and

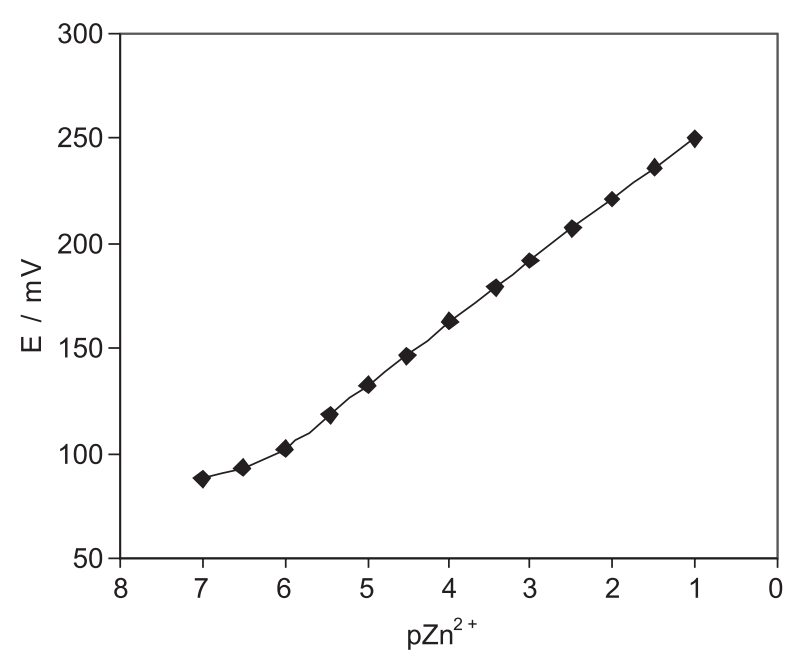

Figure 2. Calibration curve of the zinc electrode (membrane No. 7) based on BHDE at $\mathrm{pH}=5.0$.

tested over a period of 12 weeks. During this period, the electrodes were used over extended period of time (one hour per day). After 10 weeks, a slight gradual decrease in the slopes (from 29.1 to $26.5 \mathrm{mV}$ per decade) was observed.

\section{Effect of $\mathrm{pH}$ of solution on the response of the sensor}

The $\mathrm{pH}$ dependence of the membrane electrode was evaluated over a $\mathrm{pH}$ range of $2.0-10.0$ at two concentrations $\left(1.0 \times 10^{-2} \mathrm{~mol} \mathrm{~L}^{-1}\right.$ and $\left.1.0 \times 10^{-3} \mathrm{~mol} \mathrm{~L}^{-1}\right)$ of zinc ion concentration and the results are depicted in Figures $3 \mathrm{a}$ and $3 \mathrm{~b}$. As can be seen, the potential remains fairly constant in the $\mathrm{pH}$ range of $2.8-7.3$ (the $\mathrm{pH}$ of the solutions was adjusted by either $\mathrm{HNO}_{3}$ or $\mathrm{NaOH}$ solutions). Beyond this range, a gradual change in the potential was detected. The observed potential drift at the higher $\mathrm{pH}$ values could be due to the formation of some hydroxyl complexes of $\mathrm{Zn}$ (II) and insoluble zinc hydroxide, that in both cases, reduces the concentration of free $\mathrm{Zn}$ (II) in the solution. At the lower $\mathrm{pH}$ values than 2.8 , the potentials increase, indicating that the membrane sensor responds to hydrogen ions protonation of nitrogen atom in structure of BHDE. 
Dynamic response time of the Zn(II) sensor

Dynamic response time is an important factor for any ion-selective electrode. In this study, the practical response time was recorded by changing the concentration of zinc ion in solution in the range of $1.0 \times 10^{-6}$ to $1.0 \times 10^{-1} \mathrm{~mol}$ $\mathrm{L}^{-1}$ and the results are shown in Figure 4. As can be seen, in the whole concentration range the electrode reaches its equilibrium response, very fast $(<10 \mathrm{~s})$.

\section{Selectivity of the sensor}

Potentiometric selectivity coefficients of the sensor were determined by the matched potential method. ${ }^{30}$ According to this method, a specified activity (concentration) of primary ions (A, $5.0 \times 10^{-5} \mathrm{~mol} \mathrm{~L}^{-1}$ of zinc ions) is added to a reference solution $\left(1.0 \times 10^{-6} \mathrm{~mol} \mathrm{~L}^{-1}\right.$ of zinc ion) and the potential is measured. In a separate experiment, interfering ions $\left(\mathrm{B}, 1.0 \times 10^{-1} \mathrm{~mol} \mathrm{~L}^{-1}\right)$ are successively added to an identical reference solution, until the measured potential matches the one obtained before adding primary ions. The
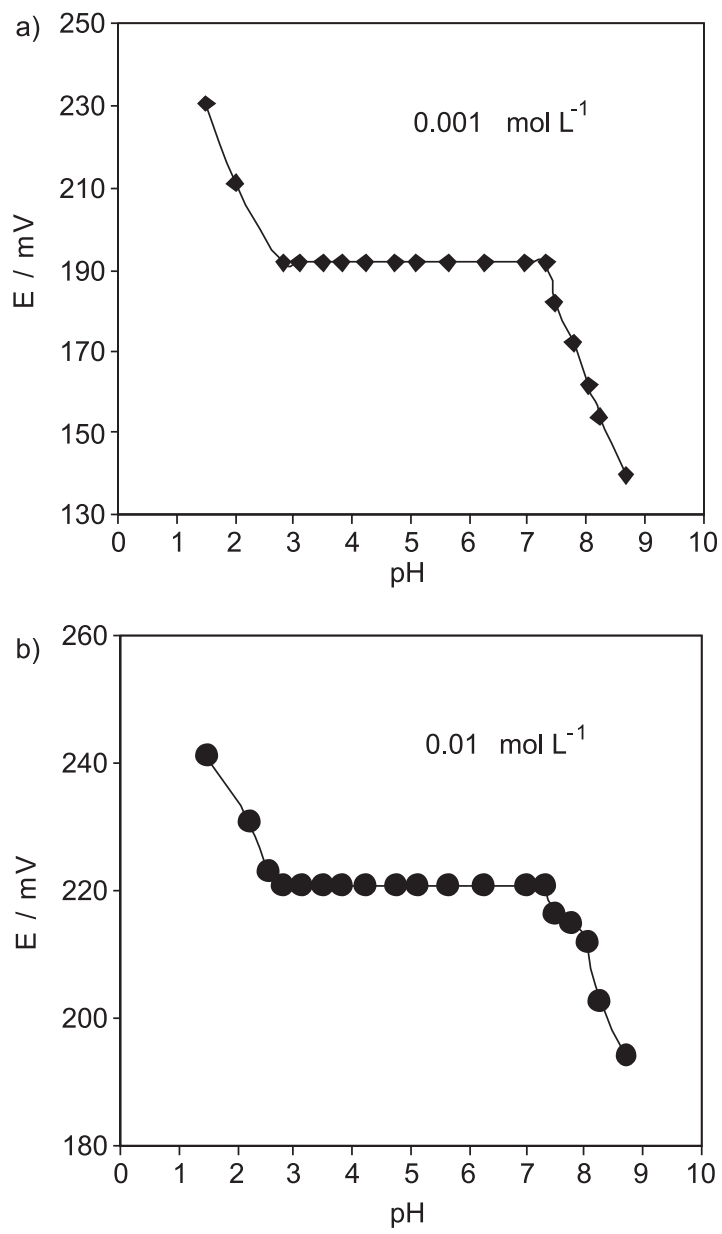

Figure 3. The effect of the $\mathrm{pH}$ of the test solutions $\left(1.0 \times 10^{-2} \mathrm{~mol} \mathrm{~L}^{-1}\right.$ and $1.0 \times 10^{-3} \mathrm{~mol} \mathrm{~L}^{-1}$ ) on the potential response of the zinc sensor (membrane No. 7).

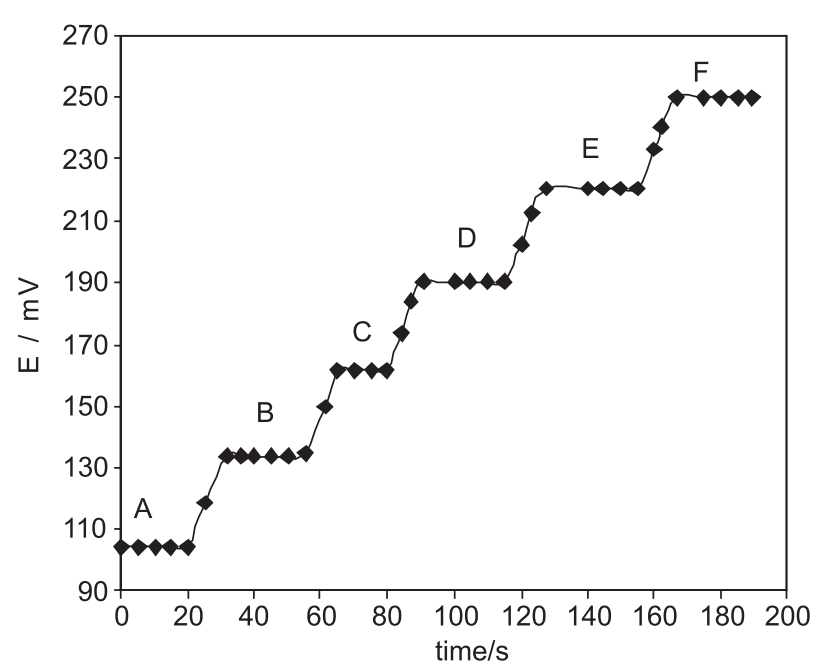

Figure 4. Dynamic response time of the zinc electrode (membrane No. 7) for step changes in the concentration of $\mathrm{Zn}^{2+}$. A) $1.0 \times 10^{-6} \mathrm{~mol} \mathrm{~L}^{-1}$; B) $1.0 \times 10^{-5} \mathrm{~mol} \mathrm{~L}^{-1}$; C) $1.0 \times 10^{-4} \mathrm{~mol} \mathrm{~L}^{-1}$; D) $1.0 \times 10^{-3} \mathrm{~mol} \mathrm{~L}^{-1}$; E) $1.0 \times$ $10^{-2} \mathrm{~mol} \mathrm{~L}-1$; F) $1.0 \times 10^{-1} \mathrm{~mol} \mathrm{~L}^{-1}$.

matched potential method selectivity coefficient, $K^{\mathrm{MPM}}$, is then given by the resulting primary ion to interfering ion activity (concentration) ratio, $K^{\mathrm{MPM}}=a_{\mathrm{A}} / a_{\mathrm{B}}$.

The resulting potentiometric selectivity coefficients values are summarized in Table 3. The data given in Table 3 , revealed that the proposed $\mathrm{Zn}$ (II) membrane sensor is highly selective with respect to most of transition and heavy metal ions. The surprisingly high selectivity of the membrane electrode for zinc ions over other cations used, most probably arises from the strong tendency of the carrier molecules for zinc ions.

Table 4 compares the selectivity coefficients, detection limit, and dynamic linearity range of the proposed sensor with the best previously reported $\mathrm{Zn}$ (II) sensors. ${ }^{3,4}, 8-12 \mathrm{As}$ seen, the proposed sensor not only, in term of selectivity, but also, in terms of detection limit and linearity range is superior than the reported $\mathrm{Zn}$ (II) sensors.

The proposed $\mathrm{Zn}(\mathrm{II})$ membrane sensor was found to work well under laboratory conditions. It was successfully applied to the titration of a $1.0 \times 10^{-4} \mathrm{~mol} \mathrm{~L}^{-1}$ zinc solution with a $1.0 \times 10^{-2} \mathrm{~mol} \mathrm{~L}^{-1}$ EDTA solution, and the resulting titration curve is shown in Figure 5. As it is seen, the

Table 3. Selectivity coefficients of various interfering ions

\begin{tabular}{llll}
\hline Ions & $\mathrm{K}_{\mathrm{Zn}^{2+}, \mathrm{B}}^{\mathrm{MPM}}$ & Ions & $\mathrm{K}_{\mathrm{Zn}^{2+}, \mathrm{B}}^{\mathrm{MPM}}$ \\
\hline $\mathrm{La}^{3+}$ & $1.8 \times 10^{-4}$ & $\mathrm{Ba}^{2+}$ & $4.0 \times 10^{-5}$ \\
$\mathrm{Ce}^{3+}$ & $9.7 \times 10^{-5}$ & $\mathrm{Mg}^{2+}$ & $3.0 \times 10^{-4}$ \\
$\mathrm{Cr}^{3+}$ & $8.7 \times 10^{-5}$ & $\mathrm{Cd}^{2+}$ & $6.8 \times 10^{-5}$ \\
$\mathrm{Li}^{+}$ & $2.7 \times 10^{-4}$ & $\mathrm{Cu}^{2+}$ & $7.2 \times 10^{-4}$ \\
$\mathrm{Na}^{+}$ & $4.2 \times 10^{-4}$ & $\mathrm{Ni}^{2+}$ & $3.4 \times 10^{-4}$ \\
$\mathrm{~K}^{+}$ & $7.0 \times 10^{-4}$ & $\mathrm{~Pb}^{2+}$ & $3.1 \times 10^{-4}$ \\
$\mathrm{Ca}^{2+}$ & $1.2 \times 10^{-4}$ & $\mathrm{Hg}^{2+}$ & $4.0 \times 10^{-4}$ \\
$\mathrm{Sr}^{2+}$ & $1.0 \times 10^{-4}$ & $\mathrm{Co}^{2+}$ & $8.6 \times 10^{-5}$ \\
\hline
\end{tabular}


Table 4. Comparison of the selectivity coefficients, detection limit, and dynamic linearity range of different $\mathrm{Zn}$ (II) electrodes

\begin{tabular}{|c|c|c|c|c|c|c|c|c|c|c|c|c|c|c|c|}
\hline \multirow{2}{*}{$\begin{array}{l}\text { Dynamic Linearity } \\
\text { Range }\left(\mathrm{mol} / \mathrm{L}^{-1}\right)\end{array}$} & \multirow{2}{*}{$\begin{array}{c}\text { Detection } \\
\text { Limit }\left(\mathrm{mol} \mathrm{L}^{-1}\right)\end{array}$} & \multicolumn{14}{|c|}{$\log \mathrm{K}_{\mathrm{Zn}^{2+}, \mathrm{M}}^{\mathrm{MPM}}$} \\
\hline & & $\mathrm{Cr}^{3+}$ & $\mathrm{Ni}^{2+}$ & $\mathrm{La}^{3+}$ & $\mathrm{Ce}^{3+}$ & $\mathrm{Pb}^{2+}$ & $\mathrm{Cd}^{2+}$ & $\mathrm{Co}^{2+}$ & $\mathrm{Ba}^{2+}$ & $\mathrm{Sr}^{2+}$ & $\mathrm{Ca}^{2+}$ & $\mathrm{Mg}^{2+}$ & $\mathrm{K}^{+}$ & $\mathrm{Na}^{+}$ & Ref. \\
\hline $1.0 \times 10^{-1}-1.5 \times 10^{-5}$ & - & -1.00 & -0.42 & - & -0.96 & -0.80 & -0.39 & -0.23 & -0.77 & -1.00 & -0.96 & -0.70 & -0.68 & -0.21 & 4 (FIM) \\
\hline $1.0 \times 10^{-1}-5.0 \times 10^{-5}$ & - & -1.55 & -1.70 & - & - & -1.60 & -1.22 & -1.70 & - & -1.60 & -1.88 & - & -1.70 & -1.19 & 5 (FIM) \\
\hline $1.0 \times 10^{-1}-1.3 \times 10^{-5}$ & - & -1.05 & -1.25 & - & - & -1.15 & -0.51 & -1.35 & - & -1.20 & -1.92 & - & -1.60 & -0.60 & 8 (FIM) \\
\hline $1.0 \times 10^{-1}-5.0 \times 10^{-5}$ & $3.0 \times 10^{-5}$ & - & -2.74 & - & - & -2.96 & -2.08 & -3.00 & -2.57 & -2.47 & -2.34 & - & -1.65 & -1.58 & 9 (FIM) \\
\hline $1.0 \times 10^{-1}-9.0 \times 10^{-5}$ & $5.0 \times 10^{-5}$ & -1.74 & -1.41 & - & - & -1.72 & -1.45 & -1.45 & -2.00 & -1.90 & -1.47 & -1.72 & -1.60 & -1.30 & 10 (FIM) \\
\hline $1.0 \times 10^{-2}-1.0 \times 10^{-6}$ & $8.5 \times 10^{-7}$ & -2.76 & -3.42 & -3.42 & -3.50 & -3.35 & -2.76 & -3.75 & -3.85 & -2.90 & -3.2 & -3.60 & -3.25 & -3.60 & 11 (FIM) \\
\hline $1.0 \times 10^{-1}-9.2 \times 10^{-5}$ & - & -0.79 & - & - & - & -0.92 & -0.48 & -0.92 & -0.92 & -0.96 & -0.89 & -0.77 & -1.57 & -1.54 & 12 (FIM) \\
\hline $1.0 \times 10^{-1}-1.0 \times 10^{-6}$ & $6.3 \times 10^{-7}$ & -4.06 & -3.47 & -3.74 & -4.01 & -3.51 & -4.17 & -4.06 & -4.40 & -4.00 & -3.92 & -3.52 & -3.15 & -3.36 & This Work \\
\hline
\end{tabular}

Table 5. Determination of $\mathrm{Zn}(\mathrm{II})$ in three industrial wastewater samples using AAS and direct potentiometry with sensor based on BHDE

\begin{tabular}{ccc}
\hline Sample No. & ISE $\left(\mathrm{mg} \mathrm{L}^{-1}\right)$ & AAS $\left(\mathrm{mg} \mathrm{L}^{-1}\right)$ \\
\hline 1 & $4.64^{\mathrm{a}} \pm 0.02$ & $4.59^{\mathrm{a}} \pm 0.05$ \\
2 & $3.46 \pm 0.05$ & $3.44 \pm 0.03$ \\
3 & $0.28 \pm 0.03$ & $0.29 \pm 0.04$ \\
\hline
\end{tabular}

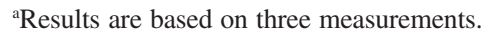

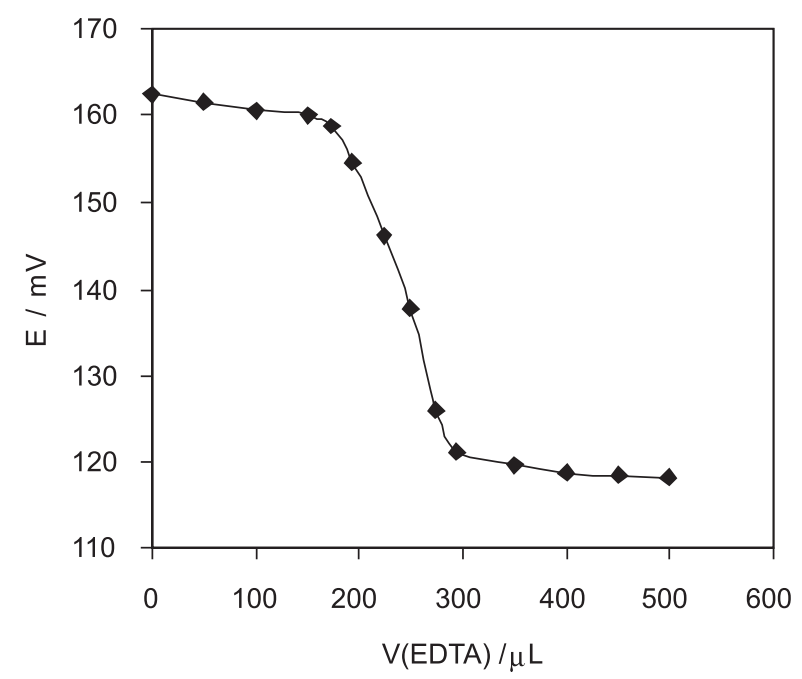

Figure 5. Potentiometric titration curve of $25.0 \mathrm{~mL} 1.0 \times 10^{-4} \mathrm{~mol} \mathrm{~L}^{-1}$ solution of $\mathrm{Zn}^{2+}$ with $1.0 \times 10^{-2} \mathrm{~mol} \mathrm{~L}^{-1}$ of EDTA.

amount of $\mathrm{Zn}^{2+}$ in solution can be determined with the good accuracy.

The electrode was also applied to the monitoring of zinc ion in a wastewater industrial zinc electroplating sample. The results (Table 5) obtained with the sensor and those of Atomic Absorption Spectrometric (AAS) analysis, were close enough for us conclude that the proposed sensor could be used in the environmental monitoring of zinc ions.

\section{References}

1. Bühlmann, P.; Pretsch, E.; Backer, E.; Chem. Rev. 1998, 98, 1593.

2. Dumkiewicz, R.; Wardak, C.; Zareba, S.; Analyst 2000, 125, 527.
3. Gupta, V.K.; Kumar, A.; Mangla, R.; Sens. Actuators, B 2001, $76,617$.

4. Jain, A.K.; Sondhi, S.M.; Rajvanshi, S.; Electroanalysis 2002, 14, 293.

5. Gupta, V.K.; Jain, A.K.; Mangla, R.; Kumar, P.; Electroanalysis 2001, 13, 1036.

6. Gholivand, M.B.; Mozaffari, Y.; Talanta 2003, 59, 399.

7. Saleh, M.B.; Abdel Gaber, A.A.; Electroanalysis 2001, 13, 104.

8. Gupta, V.K.; Chauhan, D.K.; Saini, V.K.; Agarwal, S.; Antonijevic, M.M.; Lang, H.; Sensors 2003, 3, 223.

9. Fakhari, A.R.; Shamsipur, M.; Ghanbari, K.; Anal. Chim. Acta 2002, 460, 177.

10. Ganjali, M.R.; Babaei, L.H.; Taghavaei-Ganjali, S.; Modjalal, A.; Shamsipur, M.; Hosseini, M.; Javanbakht, M.; Bull. Korean Chem. Soc. 2004, 25, 177.

11. Ganjali, M.R.; Zamani, H.A.; Norouzi, P.; Adib, M.; Rezapour, M.; Accedy, M.; Bull. Korean Chem. Soc. 2005, 26, 579.

12. Gupta, V.K.; Al Khayat, M.; Minocha, A.K.; Kumar, P.; Anal. Chim. Acta 2005, 532, 153.

13. Gupta, V.K.; Jain, A.K.; Singh, L.P.; Khurana, U.; Electrochim. Acta 1998, 43, 2047.

14. Zamani, H.A.; Rajabzadeh, G.; Firouz, A.; Ariaii-Rad, A.A.; J. Braz. Chem. Soc. 2005, 16, 1061.

15. Ganjali, M.R.; Zamani, H.A.; Norouzi, P.; Adib, M.; Accedy, M.; Acta Chim. Slov., 2005, 52, 309.

16. Zamani, H.A.; Rajabzadeh, Gh.; Ganjali, M.R.; Khatami, S.M.; Electroanalysis, in press.

17. Zamani, H.A.; Abedini-Torghabeh, J.; Ganjali, M.R.; Bull. Korean Chem. Soc., submitted

18. Zamani, H.A.; Malekzadegan, F.; Ganjali, M.R.; Anal. Chim. Acta, in press.

19. Ganjali, M.R.; Mizani, F.; Salavati-Niasari, M.; Anal. Chim. Acta 2003, 481, 85.

20. Ganjali, M.R.; Hosseini, M.; Salavati-Niasari, M.; Poursaberi, T.; Shamsipur, M.; Javanbakht, M.; Hashemi, O.R.; Electroanalysis 2002, 14, 526.

21. Ganjali, M.R.; Fathi, M.R.; Rahmani, H.; Pirelahi, H.; Electroanalysis 2000, 12, 1138.

22. Ganjali, M.R.; Javanbakht, M.; Shamsipur, M.; Mousavi, M.F.; Lippolis, V.; Garau, A.; Electroanalysis 2002, 23, 1691. 
23. Kamata, S.; Bhale, A.; Fukunaga, Y.; Murata, A.; Anal. Chem. 1998, 60, 2464.

24. Tawarah, K.M.; Mizyed, S.A.; J. Solution Chem. 1989, $18,387$.

25. Debye, P.; Huckel, E.; Phys. Z. 1928, 24, 305.

26. Takeda, Y.; Bull. Chem. Soc. Jpn. 1983, 56, 866.

27. Nicely, V.A.; Dye, J.I.; J. Chem. Educ. 1971, 48, 443.
28. Ammann, E.; Pretsch, E.; Simon, W.; Lindner, E.; Bezegh, A.; Pungor, E.; Anal. Chim. Acta 1985, 171, 119.

29. Huster, M.; Gehrig, P.M.; Morf, W.E.; Simon, W.; Anal. Chem. 1990, 63, 1330.

30. Umezawa, Y.; Umezawa, K.; Sato, H.; Pure Appl. Chem. 1995, 67, 507.

Received: July 3, 2005

Published on the web: December 15, 2005 